\title{
Spectrophotometric Determination of Acidity Constants of Group B Vitamins in Different Ionic Strengths at $25 \pm 0.1^{\circ} \mathrm{C}$
}

\author{
J. Ghasemi ${ }^{+}{ }^{*}$. S. Ghobadi+, B. Abbasi , and M. Kubista* \\ 'Department of Chemisty: Faculty of Science, Razi Lniversity; Kermanshah, Iran \\ "Deparment of Biolegy; Foculty of Science, Razi Lniversity; Kermanshah. Iran \\ "Department of Chemistry and Biosciences. Chalmers Lhnersity of Technology: Gothenhurg, Sireden \\ * MultiD Anobises $A B$, Gothenburg. Siveden
}

(2004. 10.6접수)

\section{Spectrophotometric Determination of Acidity Constants of Group B Vitamins in Different Ionic Strengths at $25 \pm 0.1^{\circ} \mathrm{C}$}

\author{
J. Ghasemi ${ }^{+*}$. S. Ghobadi+, B. Abbasi , and M. Kubista" \\ 'Department of Chemisty: Faculty of Science, Razi Lniversity; Kemanshah, Iran \\ "Department of Biology; Foculty of Science, Razi Lnversity; Kernanshah. Iran \\ "Department of Chemishy and Biosciences. Chatmers Lntiversity of Technologr; Gothenbumg. Sueden \\ \$ MultiD Anolyses $A B$, Gothenburg. Sueden
}

(Received September 6, 2004)

요 약. 25 " $\mathrm{C} \pm 0.1$ 에서 이혼세가를 달리하면서 네 가지 수횽성 비타민 - 엽산(비타민 $\mathrm{B}_{8}$ 또는 $\mathrm{B}_{\mathrm{s}}$ ), 터아민(비타민 $\mathrm{B}_{1}$ ) 러보폴라빈(비타민 $\mathrm{B}_{2}$ ) 및 피리독신(비타민 $\mathrm{B}_{6}$ )의 겉보기 산해리상수를 분광도법으로 졀정하였다. 다른 이혼세기에 서 산도상수를 결정하가 위하여, 계량화학 개념에 기초한 정교하고 정표한 방법을 분광학적 적정 네야터에 적홍하였다. 다 론 이온세.7에에 225-500 $\mathrm{nm}$ 영역에서 스펙트럳을 기록하였다. 다양한 이은세기에서 $\mathrm{pH}$-흡광도 데야터를 일-, 이- 및 삼양성자 햑산의 질량균혐방정식에 컴퓨터 펏팅하는 방법을 이용하여 떠든 비타민의 산도 상수를 계산하였다. 컨퓨터 프 로그램 DATAN을 사용하여 스펙토럽 뎨이터로부터 원하는 성보를 추출하였다. 껫팀 과성에서 산도 싱수, 순수한 형태 의 스페트럼 프로파인, 본포 도표 및 기타 인자분석 네이터롤 얻었다. 산도상수에 대한 이혼세기의 영향을 고찰하였다.

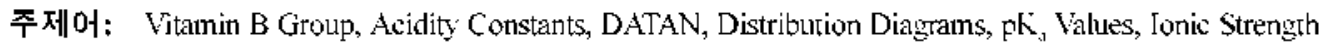

\begin{abstract}
The apparent acid dissociation constants of four water-soluble vitamins, folic acid (vitamin $\mathrm{B}_{4}$ or $\mathrm{B}_{4}$ ), thiamine (vitamin $B_{1}$ ), ribotlavin (vitamin $B_{2}$ ) and pyridoxal (vitamin $B_{0}$ ) were determined spectrophotometrically in different ionic strengths at $25^{\circ} \mathrm{C}=0.1$. An accurate and sophisticated method based on chemomerrical concepts was applied in order to determine acidity constants at different ionic strengths. For this purpose, spectral titration data were used. The spectra were recorded in the range 225-500 nm at different ionic strengths. The acidity constants of all vitamins ar various ionic strengths were calculated by means of computer fitting of the $\mathrm{pH}$-absorbance data with appropriate mass balance equations according to mono-, di- or triprotic acids. The computer program DATAN was used to extract the desired information fion the spectral data. The outputs of the fitting processes were acidity constants, spectral profiles of pure forms, distribution diagrams, and other factor analysis data. The effect of ionic strength on the acidity constants is discussed.
\end{abstract}

Keywords: Vitamin B Group, Acidity Constants, DATAN, Distribution Diagrams, $\mathrm{pK}_{4}$ Values, Jonic Strength 


\section{INTRODLCTION}

Acid dissociation constants are useful physicochemical parameters describing the extent of ionization of functional groups with respect to $\mathrm{pH}$. These parameters are important in research areas such as pharmaceutical drug development, where knowledge of the ionization state of a particular functional group often is crucial in order to understand its pharmacokinetics and pharmacodynamics.

B vitamins form a wide organic-compound group that cannot be synthesized by humans. Since these compounds are necessary for the tropism of human beings, they need to be part of our daily intake. Vitamin $B_{1}$ (Thiamine), vitamin $B_{2}$ (Ribotlavin), vitamin $B_{6}$ (Pyridoxal) and vitamin $B_{0}$ (folic acid) occur in living cells as essential substances for growth. Any deficiency of these in human nutrition will have adverse effects. Therefore, B vitamins are often supplemented to the diet as composite vitamin B tablets.

Folic acid, also known as vitamin $\mathrm{B}_{0}$ is also referred to as folacin or folate, while its chemical name is pteroylglutamic acid. Folic acid is required for DN $\Lambda$ synthesis and cell growth to take place, and it is important for the formation of red blood cells, for energy production, for the formation of amino acids. It is also required in protein metabolism and in treating folic acid anemia. ${ }^{4}$ Deficiency of folic acid is a common nutritional problem of worldwide importance. Long-term deficiency may result in anemia and later in osteoporosis, as well as cancer of the bowel and cervix.

Thiamine, also called vitamin $\mathrm{B}_{1}$, assits in a great many bodily functions. It plays a key metabolic role in the cellular production of energy, primarily in glucose metabolism. ${ }^{6.7}$ Thiamine is unstable at high $\mathrm{pHs},{ }^{8.4}$ and in food it degrades by cooking of under mildly basic conditions. ${ }^{10}$ Deficiency of vitamin $\mathrm{B}_{1}$ leads to beriberi, ${ }^{1}$ a nutritional disease characterized by degenerative changes in the nervous system, including multiple peripheral neuritis; accompanied by generalized edema and serous ettiusions, with a tendency to cardiac hypertrophy and dilation. ${ }^{11}$

Ribotlavin (vitamin $B_{2}$ ) is the prosthetic group of flavin enzymes, which are of great importance in general metabolism and particularly in metabolism of proteins. Vitamin $B_{2}$ is required for the health of the mucous membranes in the digestive tract and aidsin the absorption of iron and vitamin $\mathrm{B}_{6},{ }^{3}$ It is needed especially during periods of rapid growth. but also when protein intake is high. It is highly beneficial to the skin, hair and nails. ${ }^{*} \Lambda$ shortage of this vitamin may manifest itself as cracks and sores at the comers of the mouth, eye disorders, intlammation of the mouth and tongue, and skin lesions. ${ }^{5}$

Vitamin $\mathrm{B}_{6}$ (pyridoxal) is a common cofactor in enzymes that support amino acids metabolism. It controls the absorbtion, metabolism and conversion of amino acids into neurotransmitters, antibodies, digestive enzymes, muscles and tissues in the body. ${ }^{2}$ Deficiency of vitamin $\mathrm{B}_{6}$ may make patients prone to nerve or blood disorders, and may cause convulsions in children.":

In the present work, the protonation constants of vitamin $\mathrm{B}$ group in different concentrations of $\mathrm{KNO}_{3}$ were determined spectrophotometrically at $25^{\circ} \mathrm{C}$. The investigation of ionic strength influence on the acid-base behavior of simple organic compounds may contribute to a better understanding of the properties of complex substances such as natural organic matters.

\section{THEORY}

The theory and application of the physical constraints method have been thorouglly discussed by Kubista ef al. ${ }^{1+23}$ In the following, the general principal will be outlined briefly.

Spectra of each vitamin at different pII values and at different ionic strengths are digitized and arranged in a data matrix $A$, which is decomposed into an orthonormal basis set by NIPALS or any equivalent method: $:^{14}$

$$
\mathbf{A}=\mathbf{T} \mathbf{P}^{\prime}+\mathbf{E} \approx \mathbf{T} \mathbf{P}^{\prime}=\sum_{i}^{r} \mathrm{t}_{i} \mathbf{p}_{i}^{\prime}
$$

The orthogonal target vectors $t_{i}$ and orthonormal projection vectors $p_{i}^{\prime}$ are mathematical constructs that cannot be directly related to component spectra 
and concentrations. The symbol $r$ represents the number of independent spectroscopic components, which corresponds to the number of light-absorbing chemical species. It is determined by visual inspection of the $t$ and $p^{\dagger}$ vectors, or by applying statistical methods, such as the $\chi 2$-test. $E$ is an error matrix.

By assuming linear responses, the spectra in matrix $\boldsymbol{A}$ are linear combinations of the concentrations, $C$, and spectral responses, $\boldsymbol{V}$, of the chemical components.

$$
\mathbf{A}=\mathbf{C V}-\mathbf{E} \approx \mathbf{C V}
$$

If the spectral profiles of the components are known, the concentration of each component can be calculated easily, for example, by least squares minimization. If standards are not available, it is generally assumed that the components' spectral responses cannot be separated, which precludes their identification. This is due to ambiguity in determining the rotation matrix, $R$, in the following equations; from Eqs. (1) and (2) follows that there is a square matrix $R(r \times r)$ that satisties

$$
\begin{gathered}
T=C R \\
P^{\prime}=R^{-1} V
\end{gathered}
$$

scince $A=C V=C\left(R R^{-1}\right) V=C R\left(R^{-1} V\right)=T P^{\prime}$, If $R$ can be determined, the spectral responses $V$ and concentrations $C$ of the components can be calculated from the target $T$ and projection $P^{\prime}$ matrices:

$$
\begin{aligned}
& C=T R^{-1} \\
& V=R P^{\prime}
\end{aligned}
$$

The thermodynamic expressions that describes the concentration of the components is the main constraint used to determine $\boldsymbol{R}$, from which thermodynamic parameters, acidity constants, and components spectral responses and concentrations of all species are calculated. So, according to these facts, the strategy for determining the rotation matrix $\boldsymbol{R}$ is as follows. The concentrations of the chemical species are calculated, using equilibrium expressions and various trial values of the acidity constants, and titted to the calculated target vectors according to Eq. (3). The accuracy of this fiting depends cru- cially on the trial values of the acidity constants, and the best fit determines their values and the elements of matrix $R$.

\section{EXPERIMENTAL}

\section{Reagents}

$\Lambda l$ the chemicals were of analytical reagent grade. Four given solutions(as working solutions, folic acid, thiamine, ribotlavin and pyridoxal) were prepared in $100 \mathrm{~mL}$ volumetric tlasks by dissolving $2.00,2.00,2.50$ and $3.00 \mathrm{mg}$ of each compound in water, respectively, and the solutions were used for $\mathrm{pH}$ titration. Titration of each vitamin was carried out at five fixed ionic strengths with $\mathrm{NaOH}$ solution. The starting points of $\mathrm{pH}$ titrations were $\mathrm{pH} 2.00$, which were set using concentrated solutions of $\mathrm{HCl}$ and $\mathrm{NaOH}$. The concentrated $\mathrm{NaOH}$ solution was also used for titrations, to avoid dilution of the working solutions.

To maintain the ionic strencgth at a desired value a high concentrated solution of $\mathrm{KNO}_{\text {, was used for }}$ all titrations. $\mathrm{All}$ experiments were carried out at $25^{\circ} \mathrm{C}$. For all of the above-mentioned solutions, doubly distilled water used throughout and the solutions were kept in brown volumetric flasks to protect from light.

\section{Apparatus and software}

The $\mathrm{pH}$ values were measured by model 300 HANA $\mathrm{pH}$-meter using a combined glass electrode. The glass electrode was calibrated on the basis of the proton concentration at each constant ionic strength according to the procedure described elsewhere. ${ }^{25}$ The calibration was repeated at each ionic strength. The calibration procedure was as recommended by the IUPAC for glass electrodes. ${ }^{\text {? }}$

Absorption spectra were measured on an Agilent 8453 UV-Visible Diode-Array spectrophometer using the Agilent UV-Visisble ChemStation Sottware for data acquisition. A cell of $10 \mathrm{~mm}$ optical path was used for all measurements.

The data were preprocessed using MATL $A B$ software, version 6.5 (Mathworks, Natick, US $\Lambda$ ) and the deconvolution of the obtained data matrix 
was performed using IDATAN version 3.1.

\section{RESLLLTS AND DISCUISSION}

The electronic absorption spectra of group B vitamins were recorded in different ionic strengths and at various plI values. Sample spectra of each vitamin at different pl $\mathrm{p}$ values and at tive ionic strengths are shown in Figs. 1-4. The principal component analysis of all absorption data matrices obtained at various $\mathrm{pH}$ values shows the diflerent number of lactors for each vitamin. The number of lactors could be attributed to the number of dissociation equilibria of each vitamin. The $\mathrm{pK}_{\text {al }}$ values of group $B$ vitamins were investigated spectrophotometrically at $25^{\circ} \mathrm{C}$ in tive different ionic strengths. The acidity constants of these vitamins in several ionic strengths were evaluted by the DAIAN program using the corresponding spectral absorption-pH data. From inspection of the experimantal spectra, it is hard to guess even the number of protolytic species involved. The number of calculated projeclion vectors with clear spectral leatures, as compared to noise, shows the presence of four, three, two and three spectroscopically distinguishable components for folic acid, thiamine, riboflavin and pyridoxal, respectively.

The output of IDATAN comprises $\mathrm{pK}_{\mathrm{i}}$ values, the number of principal components, projection vectors(loadings), diagrams of the concentration distribution, and the spectrum of each assumed species. The obtained $\mathrm{pK}_{\mathrm{a}}$ values are listed in Table 1 . The $p K a$ values correspond to the pII dependent variation of absorption spectra in all ionic strengths. One of the most important outputs of the program is the calculated spectnm of dillerent forms of each vilamin al each jonic strength. The most imporlant lieatures of the distribution diagrams are the $\mathrm{pH}$ limits of the evolving and disappearing of components. Some typical distribution diagrams are shown in Fig. 5.

Consider the cationic form of pyridoxal (Scheme 1), which has two dissociable protons bound to distinctly difterent sites, the phenolic oxygen and the ring nitrogen.
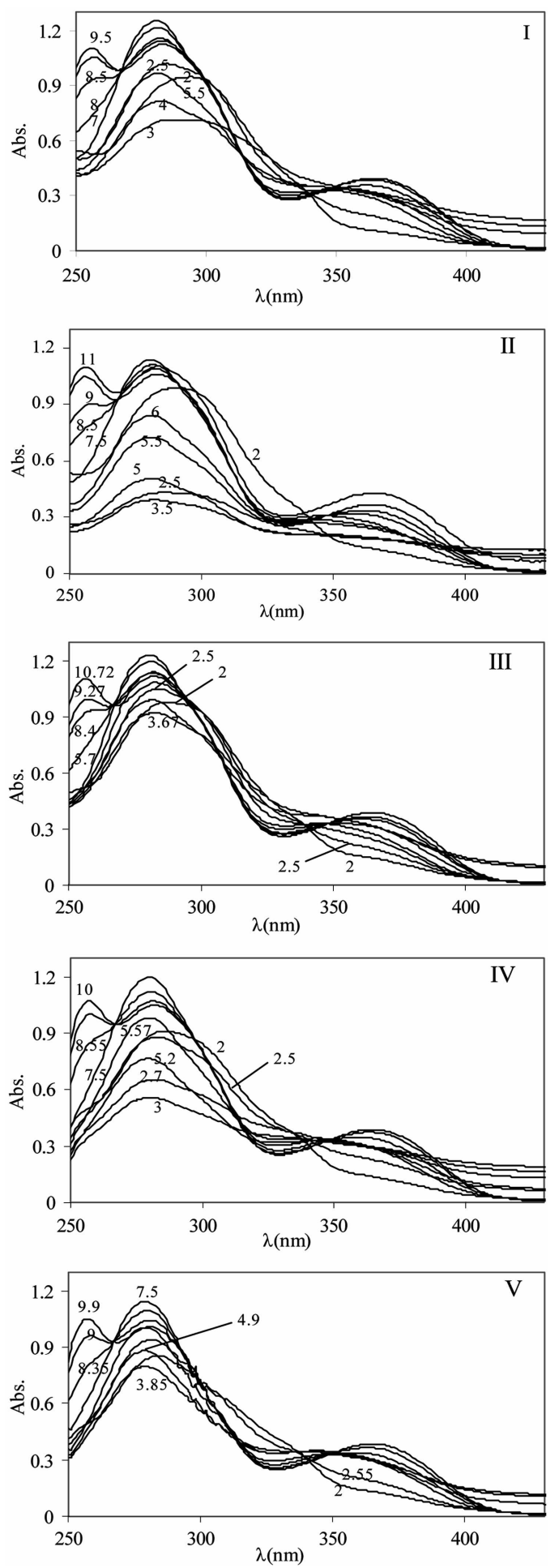

Fig. 1. Absomption specira of Folic Acid, in different concentrations of $\mathrm{KNO}$; (I) 0.00 , (II) 0.01 , (III) 0.05 , (IV) 0.10, (V) 0.30 . 

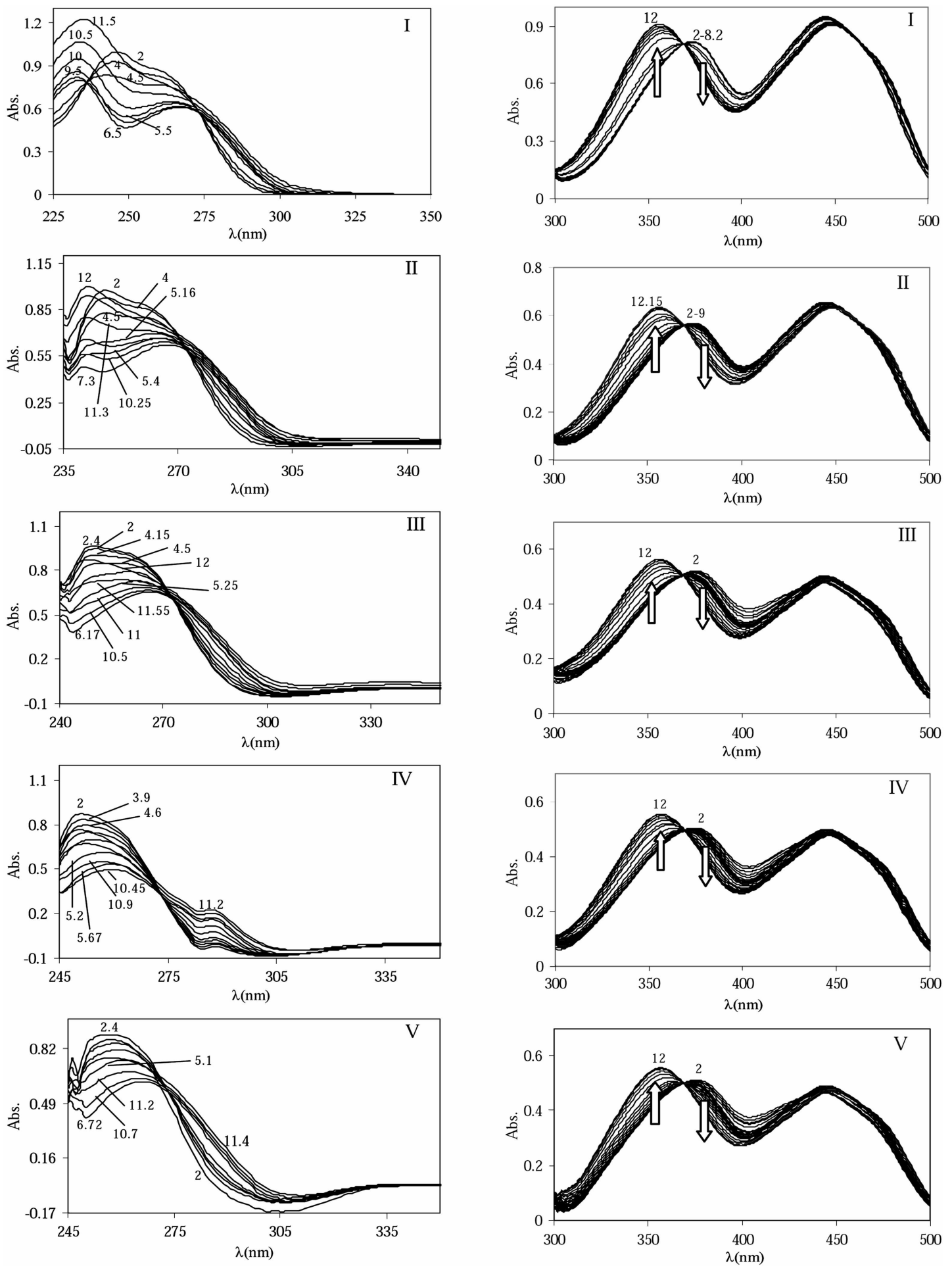

Fig. 2. Absurption spectat of Thiamine in diffentent onncentations of $\mathrm{KNO}$ : (I) 0.00, (II) 0.01. (III) 0.05, (IV) 0.10. (V) 0.30 .

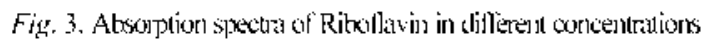
of KNO, (I) 0.00, (II) 0.01, (III) 0.05 , (IV) 0.10, (V) 0.30 .

2005.101 .45 .30 .3 

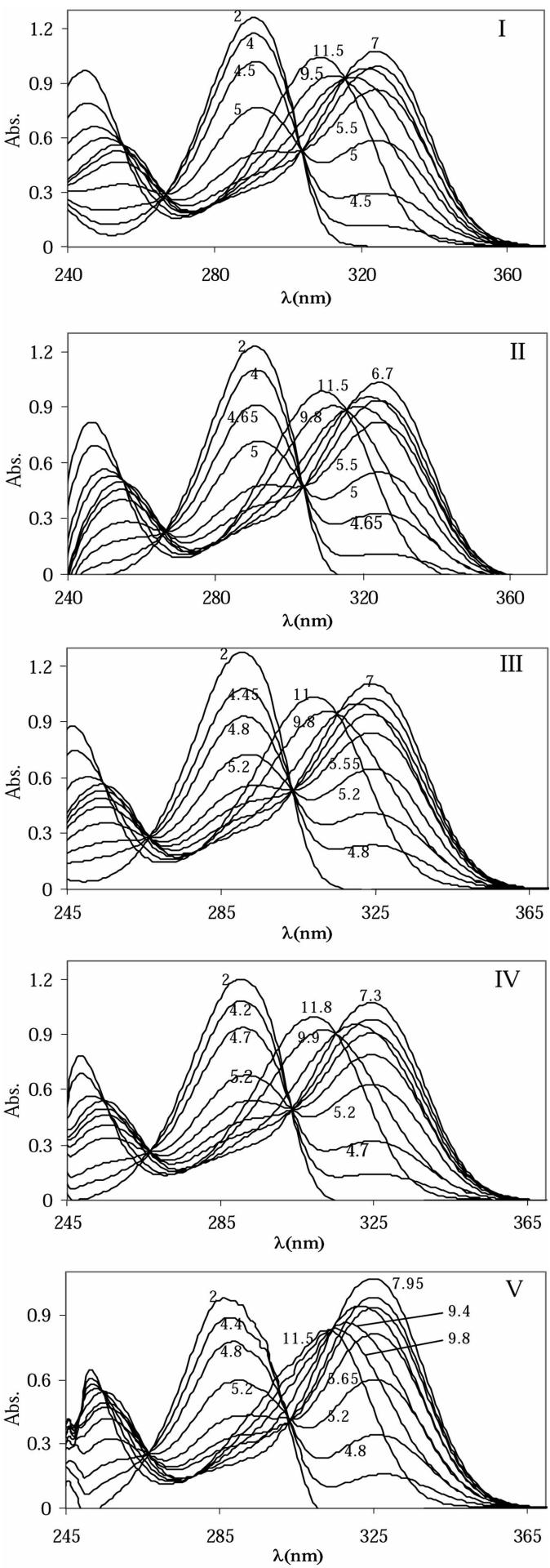

Fig. 4. Alscoption spsitra of Pyridoxid, in different concentrations ol $\mathrm{KNO}_{3}$ : (I) 0.00 , (II) 0.01 , (III) 0.05 , (IV) 0.10, (V) 0.30 .
Cither of two protons could dissociate first as the $\mathrm{pH}$ is raised. However, the two microscopic dissociation constants are distinctly different. ${ }^{-8}$ At $25^{\circ} \mathrm{C}$ in the neutral (monoprotonated) form $80 \%$ of the nolecules carry a proton on the $\mathrm{N}$, while the remaining $20 \%$ are protonated on the less basic- $\mathrm{O}^{-}{ }^{-2}$ "The obtanied $\mathrm{pK}_{1}$ and $\mathrm{pK}_{2}$ by computer fitting of spectral data are listed in Table l. The previously reported values of $\mathrm{pK}_{1}$ and $\mathrm{pK}_{2}$ at pure water are 4.64 and 8.89 , respectively. ${ }^{23}$

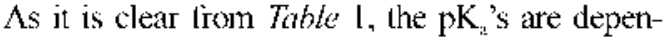
dent on the ionic strength and this in tum is due to the dependenee of the activity factors on the ionic strength. The ionic strength duc to vitamin and also buffer solution constituents is negligible, so essentially all ionic strength is due to $\mathrm{KCl}$ salt. This clearly shows that the reported values and the obtained values are more or less the same, within the experimental and instrumental errors.

Ribollavin consists of a hetrocyclic isoalloxazine ring attached to the sugar alcohol, ribitol. It is stable to heat but extremely sensitive to light. One of the products of photolysis is lumichrome. ${ }^{28}$ Freshly prepared solution ol this vilamin was used as a titration solution to deternine the corresponding acidity constant, avoiding thereby the photolysis of riboflavin. As is elcar from the structural scheme of ribotlavin (Scheme 2), which has a similar group to phthalimide, it has a dissociable proton bound to the ring nitrogen. The $\mathrm{pK}_{4}$ value obtained in this work (Toble 1) for the similar functional group is between 9.5 and $11,{ }^{\prime \prime}$ and the previously reported $\mathrm{pK}$, value for riboflavin was 10.2 . Since the change of ionic strength is associated with change of $\mathrm{pK}_{\text {. }}$ values $^{30}$ in the case of riboflavin. These variations are small and probably a more sensitive probe stach as 1luorescence spectroscopy is needed to determine the dependence of the $\mathrm{pK}_{\mathrm{s}}$ 's on the ionic strenglh.

The weakly basic portion of thiamine (Scheme 3) or of its cocnzyme form is protonated at low $\mathrm{pH}$, largely on $\mathrm{N}-1$ of the pyrimidine ring. ${ }^{31-3 .}$ The reported $\mathrm{pK}_{\mathrm{a}}$ value is -4.9 . ?h

The hydrogen atom in the 2-position of the thiazolium ring, between the sulfur and the nitrogen atoms, dissociates as $\mathrm{H}^{-}$during catalysis and the 
Spectrophotometric Detemination of Acidity Constants of Group B Vitanions in [Ditferent lonic Strengths at $25+0.1$ "C 275

Toble $\mathrm{l}$. The acidily constants of vitanins at difterent ionic strengths al $25^{\circ} \mathrm{C}$.

\begin{tabular}{|c|c|c|c|c|c|c|c|c|}
\hline \multirow{2}{*}{$\mathrm{KNO}_{3}(\mathrm{M})$} & \multicolumn{2}{|c|}{ Pyridoxal } & \multirow{2}{*}{$\frac{\text { Ribollavin }}{\mathrm{pK}_{\mathrm{ul}}}$} & \multicolumn{2}{|c|}{ Thiamine } & \multicolumn{3}{|c|}{ Folic acid } \\
\hline & $\mathrm{pK}_{\lrcorner \prime}$ & $\mathrm{pK}_{\mathrm{s}}$ & & $\mathrm{pK}_{i=1}$ & $\mathrm{pK}^{2}$ & $\mathrm{pK}_{\mathrm{ul}}$ & $\mathrm{pK}^{2}$ & $\mathrm{pK}_{\mathrm{u}, \mathrm{i}}$ \\
\hline 0.00 & 4,92 & 9.19 & 10.64 & 4.76 & 10.30 & 2.46 & 5.47 & 8.28 \\
\hline 0.01 & 4,96 & 9.42 & 10.64 & 4.98 & 11.05 & 2.63 & 5.76 & 8.78 \\
\hline 0.05 & 5.05 & 9.46 & 10.62 & 5.05 & 11.41 & 3.56 & 4.88 & 8.69 \\
\hline 0.10 & 5.06 & 9.45 & 10.58 & 5.07 & 11.04 & 2.40 & 5.35 & 8.48 \\
\hline 0.30 & 5.12 & 9.44 & 10.57 & 5.23 & 11.29 & 3.23 & 5.13 & 8.39 \\
\hline
\end{tabular}
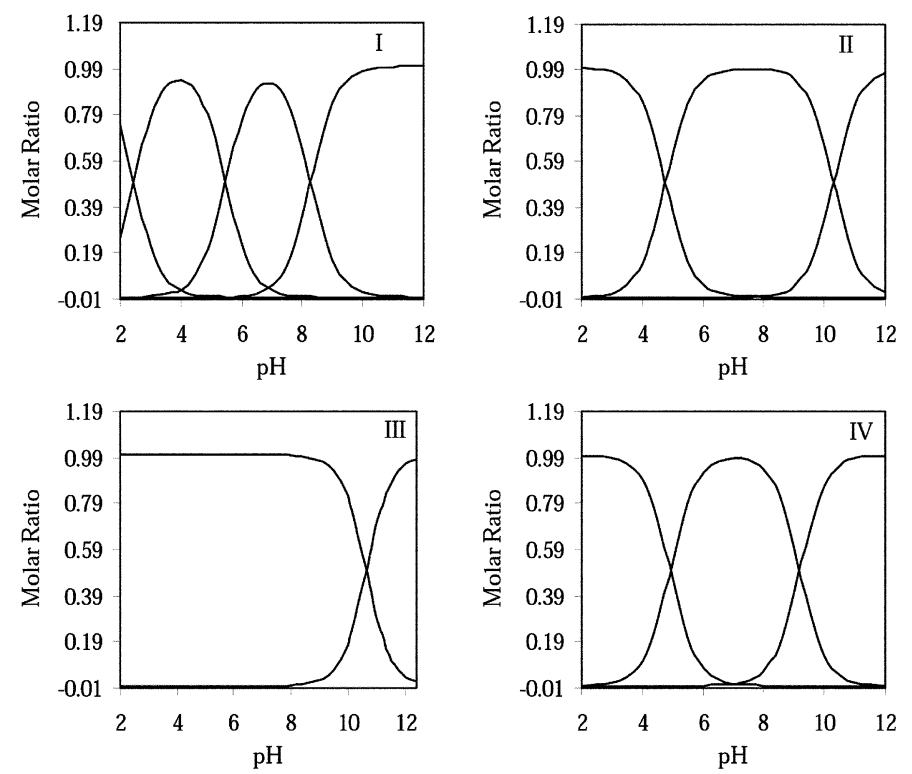

Fig. 5. Concentration distribution diagrams of (I) Folic Acid, (II) Thiamine, (III) Ribollavin and (IV) Pyridoxal, in aquecus solution at $25^{\circ}$ ' $\mathrm{C}$ and zero ionic strength.<smiles>CCCCCCCCCOC</smiles>

Sheme 1.

$\mathrm{pK}_{\mathrm{a}}$ value of this proton has becn estimated as $\sim 18$, which means that it cannot be as a acidic proton. ${ }^{34}$ The portion that can be protonated next to the $\mathrm{NH}_{2}$ group is the pyrimidine ring. The $\mathrm{pK}_{\mathrm{iL}}$ value that we obtained in this report (Table 1 ) is comparable with<smiles>[R]n1c2nc(=O)n([Tl]C(C)C)c(=O)c-2nc2cc(C)c(C)cc21</smiles>

Riboflavin<smiles>CC(C)N1C(=O)c2ccccc2C1=O</smiles>

Phthalimide

Sithom 2. 


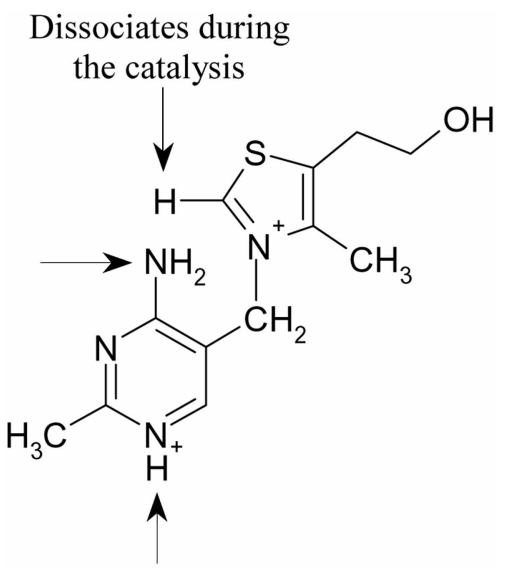

Scheme 3.

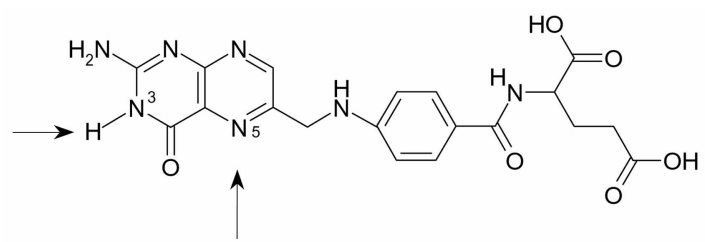

Sichence 4

previously reported values. ${ }^{2}$

The $\mathrm{pK}_{\mathrm{i} 1}$ and $\mathrm{pK}_{\mathrm{i}: 1}$ values have shown a fair dependence to ionic strenglh. $\Lambda \mathrm{s}$ it can be seen from Table 1 the higher ionic strength the higher $\mathrm{pK}_{\mathrm{a}}$ values.

The folic acid, as shown in Scheme 4, has a complicated structure and allocates the obtained acidity constants to specific groups. The previously reported $\mathrm{pK}_{\mathrm{a}}$ values are 4.82 (related to $\mathrm{N}-5$ site) and 10.5 (related to $\mathrm{N}-3$ site, transfering from $\mathrm{O}$ position to $\mathrm{N}$-position during tautonerism). ${ }^{2 .}$

Three $\mathrm{pK}_{\mathrm{i}}$ values were obtained, which are listed in Table I. $\Lambda$ s the structural scheme shows, folic acid possesses two carboxylic groups apart from the two acidic positions, as discussed above. It can be assumed that the obtained $\mathrm{pK}_{; 11}$ value relates to one of the two carboxylic groups, and the other two $\mathrm{pK}_{\text {a }}$ values can be compared with reported values, 4.82 and 10.5 for $\mathrm{pK}_{\mathrm{al}}$ and $\mathrm{pK}_{\mathrm{a} 2}$, respectively. ${ }^{2.3}$ It is surprising, to note that, the dependence of the $\mathrm{pK}_{\mathrm{d}} \mathrm{s}$ values of the folic acid on the ionic strength did not show a regular pattern. This, unlikely, is related to the no systematic changing of the absorption spec-
Ira in the course of titration, Fig. 1. And in tum these irregularitics return to this fact that folic acid solution has not enough stability and as it cleared by the manufacturer companies, the solution and the pure compound must be kept in cool and dark place.

As shown by Table 1 and Figs. 1-4, changes in ionic strengths have more or less observable effects on the spectral data of the four vitamins, which means that the acidity constants for $\mathrm{pK}_{\mathrm{s} 1}$ and $\mathrm{pK}_{\mathrm{at}}$ change mildly by changing ionic strength. Of course, they show some irregular variations, which may be due to experimental and instrumental enors in some eases. So, variation in ionic strength which have sone effects on the acidity constants of these vitamins can influence on the ionic state of these compounds as well as on the functionality of the enzymes which benefits the catalytic properties of these molecules as coenzymes.

\section{CONCLUSION}

The dissociation constants of the group B vitamins were calculated with spectrophotometric titrations using a chemometric method. The striking advantage of the proposed method is using of the whole spectral information in the computation process which enable us to have more precise and accurate thermodynamics constants in comparison to the classical methods such as single wavelength approach. The effect of the ionic strength on the acidity constants is investigated and it reveals the complex relations of the dissociation constants to the ionic strength. The results show good consistency with the previous reported results.

\section{REFERENCES}

1. Benet. L. L.: Goyan, J. E. J. Pham Scr. 1967, 56, 665.

2. Yang, 1.; Han, R.; Su, B.; l.jn, C; Wang, $\mathrm{N}$; Hu, J.: Anal. Sci. 1998, 14, 965.

3. Murray, R. K.; Gramner, D. K.; Mayes, P. A.; Rodwell, V. W., Harper's Biochemistry, twenty-fourth edition, chapter 52, 1999.

4. Belitz, H. D.; Grosch, W., Food Chemistry, second edition, Springer, chapter 6, 1999, (translation by: M. M. 
Burghagen, D. Hadziyev, P. Hesel, S. Jordan and C. Sprinz).

5. Jukes, T. H., Trentds Biochem, Sci., 1980, 5, 112.

6. Stipanuk; M. H.: Biochemical and Plysiological Aspects of Human . Vutrition, Chapters 20-21, 2000, USA.

7. Chen, Q. Y.: Li, D. H.: Yang, H. H.: Zlu, Q. Z.; Zleng, H.; Xu, J. G., Analysr. 1999, /24, 771.

8. K'luger, R.; Lam, J. F.; Pezacki, J. P.; Yang, C. M., J. Am. Chem. Soc, 1995, $117,11383$.

9. Windheuser, J. J.; Higchi, T., J. Pharm. Sci. 1962, 5/, 354.

10. D. E. Metzler, "Biochemistry; The Chemical Reactions of Living Cells", Harcourt, Academic Press, 1977.

11. Robinson, F, A., The Vitamin B Complex, Wiley, Chichester 1951, p. 57.

12. http $/ /$ www.chemicalbalance.com/sitamin b 6.htm.

13. Kubistan .,; Sjoback, R.; Albinsson, B., Anal. Chem. $1993,65,994$.

14, Scarmino, I., Kubista, M., Anal. Chem, 1993, 65, 409.

15. Kubista, M.; Sioback, R.; Nygren, J., Anal. Chm. Acta $1995,302,121$.

16. Vgren, J.; Andrade, J. M.: Kubista, M., Anal. Chem. 1996, 68, 1706.

17. Vygren, J.; Elbergali, A.; Kubista, M., Anal. Chem. $1998,70,4841$.

18. Carosena, A.; Andrade, J. M.; Kubista, M., Anal. Chem. 1995, 67, 2373.
19. Glasemi, J.; Niazi, A.; Kubista, M.; Elbergali, A., Anal. Chim. Asta. 2002, 45,5,335.

20. Ghasemi, J.; Alumadi, Slı.; Kubista, M.; Forootan, A., J. Chem. Eng. Data. 2003, 48, 1178.

21. Ghasemi, J.; Niazi, A.; Westman, Gi; Kubista, M., Talanta. 2004, 62, 835 .

22. Fisher, R.: Mackenzie, W., J. Agric. Sci. 1923, J3, 311.

23. Wold, H.; in: Daved, F. (Ed.), Research Papers in Statistics, Wiley, New York, 1966, p. 441.

24. Mardia, K. V., et al., Multivariate Analysis, Academic Press, London, 1979.

25. Brandariz, I.: Vilarino, T.: Alonso, P.: Herrero, R.: Fiol, S.: Sastre de Vicente, M. E., Talanta. 1998, 46, 1469.

26. Braibanti, A.: Ostaroli, G.: Paoleti, P.: Petit, D.: Smmartano, S., Pure Appl. Chen, 1987, 59, I72I.

27. Metzler, D. E., Biochemistry, The chemical reaction of living cells, 200I.

28. Rodriguez, H.: Suarez, M.: Perez, R.: Loupy, A., Tetrahedron Letters. 2003, 47, 3709.

29. Chemical Reagents (Merck Index) 2002, pp 855

30. Karlson P., Trends Biochem. Sci. 1984, 9, 536.

31. Panijpan, B., J. Chem. Edto 1979, $56,805$.

32. Suclyy, J.; Mieyal, J. J.; Bartle, G.; Sable, H. Z., J. Bio. Chern. 1972, 247, 5905 .

33. Breslow, R., J. An. Chem. Sox. 1958, 80, 3719.

34. Sioback, R., Nygren, J., Kubista, M., Spect. Acta part A. 1995,5$], \mathrm{L} 7=\mathrm{L} 21$. 